\title{
Review: Pembuatan Serat Rayon
}

\author{
Reynaldo Biantoro*, Chandra Apriana Purwita \\ Balai Besar Pulp dan Kertas, Jl. Raya Dayeuhkolot No. 132, Bandung, Indonesia
}

Diterima : 30 Juni 2019, Revisi akhir : 31 Oktober 2019, Disetujui terbit : 30 Desember 2019

\section{Review: Making Rayon Fiber}

\begin{abstract}
Synthetic fibers from petroleum have an important position in textile products. More than $50 \%$ of the world's fiber production is dominated by synthetic fibers. Although synthetic fibers are cheaper, high productivity, and more durable, they cannot biodegrade naturally and the manufacturing process uses materials that can damage the environment and threaten health. Increased awareness of issues related to ecology and the environment has led to the search for alternative solutions for new raw materials and the development of environmentally friendly fiber making process. Regenerated fiber is a type of semisynthetic fiber made from cellulose regeneration using renewable raw materials such as wood and non-wood which are further processed into dissolving pulp. This fiber is more environmentally friendly because it is more easily degraded. Regenerated fiber methods are more sustainable than the use of petroleum raw materials which have limited availability. In this paper, a number of methods for making rayon fibers for textiles are presented using conventional processes to alternative processes that are more environmentally friendly. These processes include nitrate, cuproammonium, acetate, viscose, lyocell, ionic solution, modal, and carbamate. The purpose of this paper is to provide comprehensive information on the various processes of making rayon fibers as well as the advantages and disadvantages, the characteristics and properties of the fibers, and the latest methods such as lyocells and ionic solutions have relatively low environmental impact so that they have the potential to be developed.
\end{abstract}

Keywords: dissolving pulp, rayon fiber, cellulose, textile, viscose

\begin{abstract}
Abstrak
Serat sintetis dari minyak bumi memiliki posisi penting dalam produk tekstil. Lebih dari $50 \%$ produksi serat dunia didominasi oleh serat sintetik. Meskipun serat sintetik lebih murah, produktivitasnya tinggi, dan lebih tahan lama tetapi serat tersebut tidak dapat terurai secara alami dan proses pembuatannya menggunakan bahan yang dapat merusak lingkungan dan mengancam kesehatan. Meningkatnya kesadaran terhadap isu-isu terkait ekologi dan lingkungan telah mendorong pencarian solusi alternatif bahan baku dan pengembangan metode pembuatan serat yang ramah lingkungan. Serat regenerasi merupakan jenis serat semisintetik yang dibuat dari hasil regenerasi selulosa yang menggunakan bahan baku terbarukan yaitu kayu dan nonkayu yang diproses lebih lanjut menjadi dissolving pulp. Serat ini lebih ramah lingkungan karena lebih mudah terdegradasi. Metode regenerasi serat selulosa lebih berkelanjutan dibandingkan penggunaan bahan baku minyak bumi yang ketersediannya terbatas. Dalam makalah ini dipaparkan sejumlah metode pembuatan serat rayon untuk tekstil menggunakan proses konvensional hingga proses alternatif yang lebih ramah lingkungan. Proses tersebut antara lain proses nitrat, cuproammonium, asetat, viskosa, lyocell, larutan ionik, modal, dan karbamat. Tujuan makalah ini adalah untuk memberikan informasi komprehensif mengenai berbagai proses pembuatan serat rayon serta keunggulan dan kelemahan yang menyertainya, karakteristik dan sifat serat yang diperoleh, dan metode terbaru seperti lyocell dan larutan ionik memiliki dampak lingkungan yang relatif rendah sehingga memiliki potensi untuk dikembangkan.
\end{abstract}

Kata kunci: dissolving pulp, serat rayon, selulosa, tekstil, viskosa 


\section{Pendahuluan}

Produk-produk tekstil umumnya dibuat dari serat, baik serat alam maupun serat buatan. Serat alam diperoleh dari tumbuhan maupun hewan seperti kapas, wol, linen, dan sutera. Sedangkan serat yang dibuat oleh manusia disebut sebagai serat buatan atau sintetis (Singh and Bhalla, 2017). Serat buatan digolongkan menjadi tiga kelompok yaitu serat yang dibuat dari polimer alam (rayon viskosa, karbamat, lyocell), serat dari polimer sintetis (poliester, nilon, akrilik, spandex, modal), dan serat dari bahan anorganik (serat logam) (Noerati et al., 2013).

Serat alam lebih nyaman digunakan, namun rendahnya produksi dan ketersediaan serta permintaan dan kebutuhan yang sangat tinggi menjadikan serat alam sangat mahal (seperti sutera). Sementara serat buatan memiliki harga yang murah, produksi yang tinggi, dan lebih tahan lama dibandingkan serat alam. Serat alam juga lebih ramah lingkungan karena mudah diuraikan oleh mikroba dimana serat ini memiliki ikatan kimia yang dapat dengan mudah dihidrolisis oleh mikroorganisme (Bajpai et al., 2011). Berbeda dengan serat alam, serat-serat buatan seperti nilon dan poliester umumnya tidak dapat terurai secara alami, serta produksinya melibatkan proses yang mengancam lingkungan dan kesehatan manusia.

Pada saat ini lahan pertanian dunia yang ditanami kapas hanya sekitar 2,5\%. Hal ini tidak akan mencukupi kebutuhan kapas dunia. Meningkatnya permintaan serat kapas juga menyebabkan peningkatan penggunaan herbisida dan pestisida serta penggunaan pupuk dalam jumlah besar untuk monokultur kapas (Latif et al., 2018). Meskipun serat kapas berkelanjutan, namun produksi $1 \mathrm{~kg}$ serat kapas memerlukan lebih dari 20.000 liter air, menggunakan $24 \%$ insektisida dan $11 \%$ pestisida (Basit et al., 2019). Untuk memenuhi kebutuhan serat tekstil selain kapas, disamping meningkatnya perhatian akan dampak lingkungan akibat penggunaan polimer sintetik yang sulit didegradasi dari sumber daya yang tidak terbarukan, telah mendorong pencarian solusi alternatif bahan baku. Hal ini menjadikan selulosa sebagai sumber alternatif yang sangat baik sebagai pengganti serat polimer berbasis minyak bumi (Manian, Pham and Bechtold, 2018).

Pada tahun 2016, konsumsi serat dunia didominasi oleh poliester (55\%), kapas (27\%), dan serat selulosa (7\%). Kelompok serat selulosa terdiri dari jenis viskosa, asetat, lyocell, modal, dan cuproammonium. Viskosa berperan penting karena menguasai $80 \%$ pangsa pasar serat selulosa. Meskipun pangsa pasar viskosa saat ini masih relatif lebih kecil jika dibandingkan dengan kapas atau poliester, namun pertumbuhan produksi viskosa untuk industri tekstil diperkirakan akan semakin meningkat pada tahun-tahun mendatang (Freitas, Zhang and Mathews, 2017). Penggunaan serat rayon pada tahun 2019 diprediksi akan meningkat hingga $9-10 \%$ yaitu senilai 16 milyar dolar atau sebanyak 7,2 juta ton dibandingkan tahun 2014 (Andemars et al., 2018). Faktor utama pendorong tingginya kebutuhan produk tekstil adalah pertumbuhan ekonomi dan populasi. Kebutuhan serat tekstil diproyeksikan akan meningkat dari 72,5 juta ton pada tahun 2010 menjadi 133,5 juta ton pada tahun 2030 (Hämmerle, 2011). Peningkatan permintaan terhadap serat selulosa juga terjadi pada industri lain seperti bidang medis dan kesehatan (Sixta et al., 2013; Li, Sevastyanova and Ek, 2012). Sebaran produksi jenis-jenis serat dapat dilihat pada Gambar 1 dan 2.

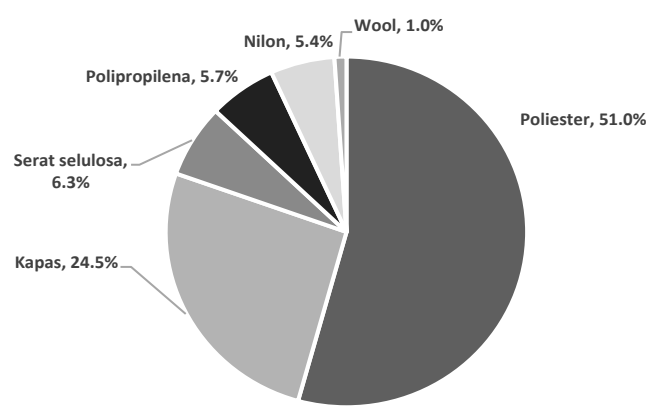

Gambar 1. Produksi Serat Tekstil Global Tahun 2017 (Truscott, Tan and Opperskalski, 2018)

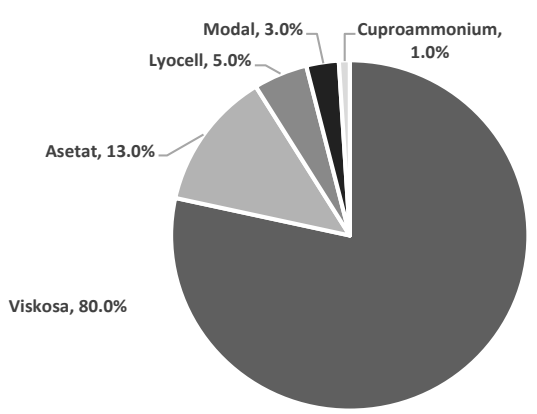

Gambar 2. Produksi Serat Selulosa Tahun 2017 (Truscott, Tan and Opperskalski, 2018) 
Serat viskosa merupakan salah satu jenis serat semisintetik yang dibuat dari proses regenerasi selulosa. Sumber selulosa adalah hardwood, softwood, serta non-wood. Selulosa pada bahan baku tersebut diproses menjadi pulp khusus yang memiliki karakteristik tertentu, disebut dissolving pulp. Saat ini dissolving pulp yang tersedia secara komersial berasal dari hardwood dan softwood. Dissolving pulp merupakan pulp khusus yang memiliki kandungan selulosa alfa serta derajat cerah yang tinggi sedangkan kandungan ekstraktif, hemiselulosa, dan abu rendah serta memiliki ketahanan terhadap larutan alkali yang lebih baik (Purwita and Sugesty, 2018). Kandungan selulosa alfa pada dissolving pulp harus lebih tinggi dari 90\% (Sixta, 2006), rendah kandungan hemiselulosa (2-4\%), rendah lignin, ekstraktif dan mineral. Selain itu dissolving pulp memiliki keunggulan dibandingkan pulp kertas, yaitu reaktivitas selulosa tinggi, dan distribusi berat molekul seragam (Köpcke, 2010; Li, Sevastyanova and Ek, 2012). Sekitar 70\% aplikasi dissolving pulp adalah untuk membuat serat selulosa melalui proses viskosa (Sango et al., 2018). Spesifikasi standar dissolving pulp sebagai bahan baku viskosa maupun produk lainnya dapat dilihat pada Tabel 1 dan 2.

Tabel 1. Standar Mutu Dissolving Pulp SNI 9382017

\begin{tabular}{clcc}
\hline No & Parameter & Satuan & Persyaratan \\
\hline 1 & Selulosa alfa & $\%$ & min. 94 \\
2 & $\mathrm{~S}_{18}$ & $\%$ & maks. 4,9 \\
3 & $\mathrm{~S}_{10}$ & $\%$ & maks. 7,9 \\
4 & Kadar ekstraktif & $\%$ & maks. 0,2 \\
& (diklorometana) & & \\
5 & Kadar abu & $\%$ & maks. 0,15 \\
6 & Kadar abu tidak larut & ppm & maks.100 \\
& asam & & \\
7 & Kadar kalsium & ppm & maks.150 \\
8 & Kadar besi (sebagai & ppm & maks.10 \\
& Fe) & & \\
9 & Viskositas (intrinsik) & mL/g & min. 370 \\
10 & Viskositas & mPa.s & min. 6,2 \\
& (kuprietilendiamina) & atau cP & \\
11 & Derajat cerah & $\%$ ISO & min. 88 \\
12 & Kadar air & $\%$ & maks. 12 \\
\hline
\end{tabular}

Tabel 2. Spesifikasi Standar Dissolving Pulp menurut Kebutuhan Aplikasinya (Sixta, 2016)

\begin{tabular}{|c|c|c|c|c|}
\hline \multirow{2}{*}{ Parameter } & \multirow{2}{*}{ Satuan } & \multicolumn{3}{|c|}{ Aplikasi } \\
\hline & & Serat viskosa & Selulosa asetat & Ether \\
\hline \multicolumn{5}{|c|}{ Makromolekular } \\
\hline Viskositas intrinsik & $\mathrm{mL} / \mathrm{g}$ & $450-500$ & $650-900$ & $>1500$ \\
\hline $\mathrm{DP}<100$ & - & $3-6$ & $<2$ & 0 \\
\hline \multicolumn{5}{|c|}{ Ketahanan alkali } \\
\hline R18 & $\mathrm{wt} \%$ & $94-97$ & $97,5-98,5$ & $\sim 95$ \\
\hline R10 & $\mathrm{wt} \%$ & $89-92$ & $94-98$ & $\sim 94$ \\
\hline \multicolumn{5}{|l|}{ Pengotor organik } \\
\hline Hemiselulosa (Xyl+Man+) & $\mathrm{wt} \%$ & $3-5$ & $1-2$ & $4-6$ \\
\hline Ekstraktif aseton & $\mathrm{wt} \%$ & 0,2 & 0,05 & 0,1 \\
\hline Lignin (Bilangan Kappa) & - & $<0,3$ & $<0,2$ & $<0,5$ \\
\hline \multicolumn{5}{|c|}{ Anorganik } \\
\hline Kadar abu & wt $\%$ & 0,1 & $<0,08$ & $<0,2$ \\
\hline $\mathrm{Mn}$ & ppm & $<0,5$ & $<0,5$ & 0,5 \\
\hline $\mathrm{Fe}$ & ppm & $<5$ & $<3$ & $<5$ \\
\hline $\mathrm{Ca}$ & ppm & $<20$ & $<15$ & $<50$ \\
\hline $\mathrm{Si}$ & ppm & $<20$ & $<10$ & $<15$ \\
\hline \multicolumn{5}{|c|}{ Sifat fisik } \\
\hline Kecerahan & $\%$ ISO & $89-93$ & $>92$ & $>85$ \\
\hline Kepadatan & g.cm-3 & $\sim 0,9$ & $<0,55$ & $\sim 0,8$ \\
\hline
\end{tabular}




\section{Produksi Serat Selulosa}

Selulosa disusun dari rantai-rantai linear polimer glukosa dan membentuk struktur-struktur supramolekul yang berikatan hidrogen dengan kuat, sehingga selulosa tidak mudah larut dalam pelarut organik biasa (Cai et al., 2009). Maka dari itu untuk memperoleh serat regenerasi atau produk derivat selulosa lain yang bernilai komersial tinggi, selulosa perlu untuk direaksikan terlebih dahulu. Gugus hidroksil pada selulosa dapat direaksikan sebagian atau seluruhnya dengan bahan kimia tertentu. Proses esterifikasi maupun eterifikasi gugus hidroksil merupakan reaksi utama untuk semua derivat selulosa yang tersedia secara komersial saat ini. Proses esterifikasi menghasilkan ester selulosa (misalnya selulosa asetat, selulosa xanthat, dan selulosa karbamat), sedangkan eterifikasi menghasilkan eter selulosa (metil selulosa, karboksimetil selulosa dan hidroksi-propil selulosa) (Cuissinat, Navard and Heinze, 2008; Keshipour and Maleki, 2019).

Serat rayon merupakan serat tekstil yang diperoleh melalui proses pembuatan selulosa xanthat (viskosa) maupun selulosa karbamat (Cuissinat, Navard and Heinze, 2008). Selain itu ada beberapa metode lain pembuatan serat rayon tekstil dari selulosa seperti menggunakan asam nitrat, asetat, cuproammonium, lyocell, larutan ionik, dan modal.

\section{Metode Konvensional}

\subsection{Serat Buatan Pertama}

Pada tahun 1734, Rene Antoine de Reaumur menyatakan bahwa sutera tidak lain adalah getah cair yang dikeringkan. Dia melaporkan telah membuat serat mirip sutera dengan cara memaksa berbagai jenis bahan pelapis/pengeras melalui lubang kecil dibawah kaleng besi untuk membentuk benang lengket yang mengeras saat terkena udara. Serat yang dihasilkannya tidak memiliki nilai penting, namun proses pembuatannya menjadi dasar dari seluruh percobaan masa mendatang dalam upaya menghasilkan serat buatan (Kauffman, 1993).

\subsection{Proses Nitrat}

Prinsip pembuatan selulosa nitrat ditemukan pertama kali secara tidak sengaja oleh Christian Friedrich Schonbein tahun 1846. Ia mereaksikan selulosa dengan asam sulfat dan asam nitrat sehingga menghasilkan derivat selulosa yang disebutnya guncotton (Kauffman, 1993). Meskipun Christian Friedrich Schonbein adalah penemu pertama, tetapi paten Inggris pertama untuk produksi serat selulosa nitrat diperoleh tahun 1855 oleh George Audemars melalui hasil reaksi antara selulosa dengan asam nitrat. Campuran tersebut kemudian dilarutkan dalam alkohol dan eter (disebut larutan collodion) sehingga dapat ditarik keluar menjadi benang atau filamen halus (Woodings, 2001). Serat selulosa nitrat yang diperoleh bersifat kuat dan lembut, serta dapat ditenun menjadi kain. Namun serat tersebut memiliki kelemahan utama yang menghalangi digunakan secara luas dalam industri tekstil yaitu: serat tersebut sangat mudah terbakar.

Tahun 1892 Chardonnet berhasil menyempurnakan proses ini yaitu dengan melakukan denitrasi selulosa nitrat menggunakan ammonium hidrosulfat, kemudian larutan collodion diekstrusi melalui lubang-lubang spinneret dan dilewatkan melalui udara hangat untuk menguapkan pelarut dan membentuk filamen selulosa nitrat padat. Proses pembuatan serat metode asam nitrat ini sederhana dalam konsep, namun sangat lambat dalam pelaksanaannya, sulit untuk dilakukan scale-up dengan aman, dan kurang ekonomis dibandingkan dengan metode lainnya. Walaupun telah dilakukan proses denitrasi serat dengan seksama, namun kemungkinan resiko terbakar tetap besar sehingga merusak kekuatan dan penampilan serat secara keseluruhan (Woodings, 2001).

\subsection{Proses Cuproammonium}

Pada tahun 1857 Matthias Schweizer menemukan bahwa kapas dapat dilarutkan dalam larutan garam tembaga dan amonia, dilanjutkan dengan proses regenerasi dalam bak koagulasi sehingga diperoleh serat (Gambar 3). Proses ini selanjutnya disempurnakan hingga tahap pemintalan seratoleh Louis-Henri Despeissis yaitu dengan mengekstrusi larutan cuprammonium selulosa ke dalam air, selanjutnya penambahan asam sulfat encer akan menetralkan amonia dan menghasilkan serat selulosa (Woodings, 2001).

Serat rayon cuprammonium banyak digunakan untuk pakaian, jok, kain dekoratif. Namun proses pembuatannya berbahaya untuk lingkungan karena pelepasan tembaga dalam aliran limbah. Proses ini ilegal untuk digunakan di Amerika Serikat. Masalah utama lainnya adalah 


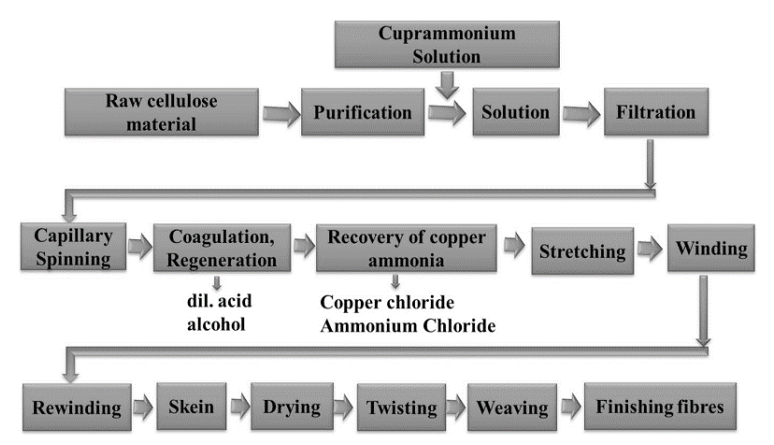

Gambar 3. Alur Proses Pembuatan Serat Cuproammonium (Woodings, 2001)

penggunaan bahan kimia berbahaya yang boros seperti garam tembaga, natrium hidroksida, asam sulfat dan amonia yang korosif sehingga proses ini memerlukan biaya yang tinggi (Sayyed, Deshmukh and Pinjari, 2019). Sebagian besar produsen telah meninggalkan metode ini seiring dengan pecahnya perang pada tahun 1914 (Woodings, 2001).

\subsection{Proses Asetat}

Ester organik selulosa pertama disintesis dari reaksi selulosa kapas dengan asetat anhidrida dalam tabung tertutup pada suhu $180^{\circ} \mathrm{C}$ oleh Schutzenberger tahun 1865 (Keshipour and Maleki, 2019). Produksi Ester asetat selulosa pertama dalam skala komersial adalah pada tahun 1923 oleh Celanese. Serat selulosa asetat diperoleh dengan mereaksikan selulosa dengan $\mathrm{NaOH}$, kemudian dicuci dengan $\mathrm{HCl}$ dan direndam dalam asam asetat glasial untuk reaksi asetilasi. Pemeraman dilakukan dalam larutan asam asetat dan asam sulfat. Kemudian ditambahkan titanium dioksida sebagai delustran untuk mengurangi transparansi dan kemilau serat, serta membentuk permukaan serat agar kasar. Selanjutnya larutan selulosa dope diekstrusi melalui spinneret dan pelarut pada serat kemudian diuapkan sehingga diperoleh benang (proses pemintalan kering). Titanium dioksida yang digunakan dikenal sebagai senyawa yang beracun (Singh and Bhalla, 2017; Sayyed, Deshmukh and Pinjari, 2019). Alur proses pembuatan serat asetat seperti pada Gambar 4.

Selulosa asetat digunakan dalam bidang medis seperti untuk sistem penghantaran obat, pembalut luka, membran pemisah, dan lainnya (Suwantong and Supaphol, 2015). Namun pasar terbesar untuk selulosa asetat didominasi oleh industri filter rokok hingga 80\% pasar tahun 2014

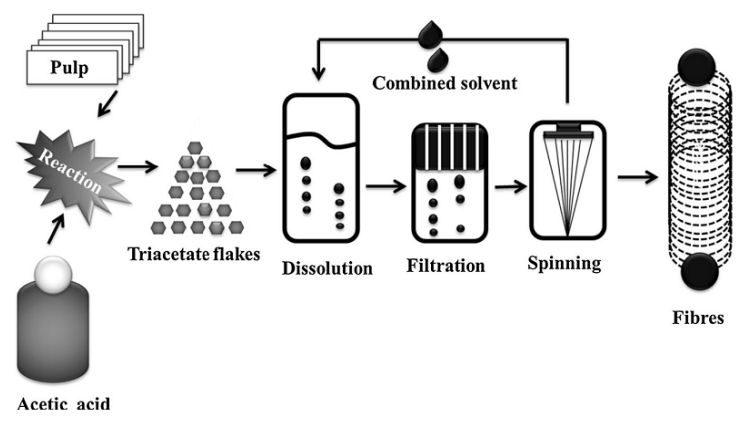

Gambar 4. Alur Proses Pembuatan Serat Asetat (Sayyed, Deshmukh and Pinjari, 2019).

dan diharapkan dominan hingga 2023. Tekstil dan pakaian jadi adalah segmen aplikasi terbesar kedua pasar selulosa asetat global tahun 2014 (Sayyed, Deshmukh and Pinjari, 2019). Walaupun permintaan melambat, serat asetat memiliki tempatnya sendiri diantara keluarga serat tekstil lainnya (Rustemeyer, 2004). Serat asetat adalah serat khusus dengan karakteristik tertentu yang tetap diinginkan bahkan di pasar yang menurun (Law, 2004).

Serat selulosa asetat masih memiliki kelemahan seperti pada kekuatan serat yang rendah (lebih lemah daripada rayon viskosa) (Sayyed, Deshmukh and Pinjari, 2019), sedangkan kebutuhan saat ini adalah serat dengan kekuatan yang lebih tinggi untuk mesin-mesin produksi tekstil berkecepatan tinggi (Rustemeyer, 2004). Selain itu serat selulosa asetat memiliki ketahanan abrasi yang rendah, dan ketahanan suhu yang buruk. Kain asetat juga sensitif terhadap perubahan warna karena polusi udara dan memiliki kecenderungan yang tinggi untuk mengumpulkan listrik statis (Sayyed, Deshmukh and Pinjari, 2019).

\subsection{Proses Viskosa}

Proses viskosa merupakan proses utama yang masih digunakan didunia saat ini untuk memperoleh serat dari selulosa (Gambar 5). Charles Cross, Edward Bevan, dan Clayton Beadle pada tahun 1891 menemukan bahwa kapas ataupun selulosa kayu dapat dilarutkan menjadi selulosa xanthat melalui perlakuan alkali dan karbon disulfida $\left(\mathrm{CS}_{2}\right)$ (Woodings, 2001; Zhang et al., 2018). Paten penting tahun 1898 terkait dengan viskosa adalah metode menggumpalkan viskosa membentuk benang melalui larutan alkohol, air garam, ammonia 


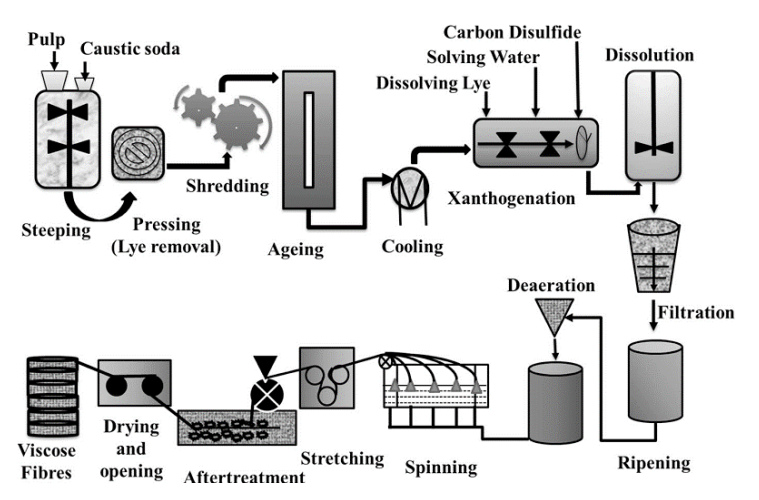

Gambar 5. Alur Proses Pembuatan Serat Rayon Viskosa (Sayyed, Deshmukh and Pinjari, 2019).

sulfat, klorida, serta larutan koagulan lainnya. Paul Koppe mematenkan spinbath yang berisi campuran dari asam sulfat dan garam terlarut lain di tahun 1904. Serat rayon pertama kali dikomersialkan oleh perusahaan Inggris Samuel Courtauld \& Company tahun 1905, dan pertama kali diproduksi di AS tahun 1911 oleh American Viscose Corporation. Serat rayon berkinerja tinggi baru dikembangkan kemudian pada tahun 1947 (Baker, 2018).

Beberapa tahun awal produksi viskosa memiliki masalah utama seperti hasil yang tidak konsisten dan sebagian besar proses tidak dapat terkontrol. Pengembangan dan peningkatan pada tahun-tahun berikutnya semakin menyempurnakan proses viskosa. Baru setelah tahun 1910an, proses viskosa dapat disebut sebagai proses pembuatan serat unggul yang menghasilkan benang berkualitas dengan harga yang bersaing. Output yield serat dari proses viskosa mungkin hanya sepertiga dari produksi selulosa nitrat dan setengah dari produksi cuproammonium, namun viskosa memiliki keunggulan lain dari sisi teknologi dan ekonomi. Saat ini sebagian besar serat rayon dibuat menggunakan proses viskosa dimana selulosa direaksikan dengan larutan natrium hidroksida $(\mathrm{NaOH})+$ karbon disulfida $\left(\mathrm{CS}_{2}\right)$ dan proses ini telah bertahan selama lebih dari 70 tahun. Alur proses pembuatan serat rayon viskosa disajikan pada Gambar 5.

Bahan baku pembuatan serat rayon viskosa adalah bubur kayu (pulp) yang dimurnikan (dissolving pulp). Pulp tersebut diubah menjadi selulosa alkali oleh natrium hidroksida. Karbon disulfida berperan mengubah selulosa alkali menjadi natrium selulosa xantat, yang selanjutnya dilarutkan dalam larutan soda kaustik encer. Larutan ini lalu diperam dan kemudian dipintal secara pemintalan basah melalui larutan koagulasi asam kuat (Strunk, 2012). Berikut ini adalah tahapan proses pembuatan serat rayon viskosa.

\section{a. Alkalisasi}

Pulp direndam dalam larutan $\mathrm{NaOH}(17-20 \%)$ dengan tujuan untuk membentuk slurry alkali selulosa, memecah ikatan hidrogen antar molekul selulosa, mengubah struktur kristalin selulosa, menghilangkan kotoran, serta memisahkan dan melarutkan hemiselulosa dalam $\mathrm{NaOH}$. Persamaan reaksi alkalisasi seperti dibawah ini.

$$
\left(\mathrm{C}_{6} \mathrm{H}_{10} \mathrm{O}_{5}\right)^{\mathrm{n}}+\mathrm{nNaOH} \longrightarrow\left(\mathrm{C}_{6} \mathrm{H}_{9} \mathrm{O}_{4} \mathrm{ONa}\right)_{\mathrm{n}}+\mathrm{nH}_{2} \mathrm{O}
$$

\section{b. Pemerasan (Pressing)}

Pemerasan dilakukan untuk mengeluarkan kelebihan larutan $\mathrm{NaOH}$ dan mengeluarkan selulosa rantai pendek yang larut.

\section{c. Pencabikan (Shredding)}

Pencabikan bertujuan untuk memperbesar luas permukaan alkali selulosa agar molekul oksigen dari udara dapat lebih mudah masuk ke dalam molekul selulosa dan meningkatkan reaktivitas terhadap $\mathrm{CS}_{2}$, diperoleh serbuk alkali selulosa disebut crumb.

\section{d. Pemeraman (Ageing)}

Proses pemeraman berguna untuk menurunkan derajat polimerisasi (depolimerisasi) alkali selulosa dari 1000-2000 menjadi 300-500, serta untuk menyeragamkan derajat polimerisasinya agar diperoleh viskosa yang baik kekentalannya.

\section{e. Xantasi}

Pada proses ini terjadi reaksi esterifikasi gugus hidroksil dalam suasana basa, interaksi antara alkali selulosa dengan $\mathrm{CS}_{2}$. Tujuannya adalah mengubah selulosa menjadi selulosa xantat yang mudah dilarutkan, dan ketika selulosa xantat dilarutkan akan diperoleh viskosa yang homogen. Pada saat xantasi terjadi pula reaksi samping antara $\mathrm{NaOH}$ dan $\mathrm{CS}_{2}$ menjadi produk yang tidak diinginkan, sehingga kelebihan $\mathrm{NaOH}$ harus benar-benar dihilangkan. Persamaan reaksi xantasi seperti dibawah ini. 
$\left(\mathrm{C}_{6} \mathrm{H}_{9} \mathrm{O}_{4} \mathrm{ONa}\right)_{n}+\mathrm{nCS}_{2} \longrightarrow[\mathrm{S}=\mathrm{C}^{\prime} \overbrace{\mathrm{OC}_{6} \mathrm{H}_{9} \mathrm{O}_{4}}^{\mathrm{SNa}}]$

\section{f. Pelarutan (Dissolving)}

Pelarutan selulosa xantat dilakukan dalam $\mathrm{NaOH}$ dingin $\left(10^{\circ} \mathrm{C}\right)$ untuk menghindari dekomposisi xantat berlebihan dan pembentukan produk samping. Larutan yang terbentuk dari proses dissolving ini yang dikenal sebagai viskosa. Persamaan reaksi pelarutan selulosa xantat dalam $\mathrm{NaOH}$ seperti dibawah ini.

$$
3 \mathrm{CS}_{2}+6 \mathrm{NaOH} \longrightarrow \mathrm{Na}_{2} \mathrm{CO}_{3}+2 \mathrm{Na}_{2} \mathrm{CS}_{3}+3 \mathrm{H}_{2} \mathrm{O}
$$

\section{g. Pematangan (Ripening)}

Proses pematangan larutan viskosa ini bertujuan untuk menyempurnakan reaksi pembentukan viskosa. Larutan viskosa disimpan dalam ruangan dingin dengan suhu $11-20{ }^{\circ} \mathrm{C}$ selama 9-25 jam. Viskosa disaring untuk memisahkan kotoran dan partikel yang tidak larut serta perlu dihilangkan gelembung-gelembung udara.

\section{h. Pemilinan (Spinning)}

Pembuatan serat rayon menggunakan metode pemilinan basah; larutan viskosa dialirkan melalui spineret ke dalam bak berputar yang berisi asam sulfat (untuk meregenerasi viskosa menjadi selulosa dalam bentuk filamen serat), natrium sulfat (mempercepat koagulasi viskosa dan melindungi filamen serat dari kerusakan oleh asam), dan seng sulfat (menghambat proses regenerasi dengan membentuk lapisan kulit filamen serat yang lebih stabil). Persamaan reaksi regenerasi viskosa menjadi selulosa seperti dibawah ini

$\left(\mathrm{C}_{6} \mathrm{H}_{9} \mathrm{O}_{4} \mathrm{O}-\mathrm{SC}-\mathrm{S}_{\mathrm{na}}\right)^{\mathrm{n}}+(\mathrm{n} / 2) \mathrm{H}_{2} \mathrm{O} \rightarrow\left(\mathrm{C}_{6} \mathrm{H}_{10} \mathrm{O}_{5}\right)^{\mathrm{n}}+\mathrm{nCS}_{2}+(\mathrm{n} / 2) \mathrm{Na}_{2} \mathrm{SO}_{4}$

\section{i. Pencucian dan Penyempurnaan Serat}

Serat rayon dicuci dengan: air panas selama 5 menit untuk menghilangkan asam yang terbawa dari larutan koagulasi, pencucian dengan $\mathrm{Na}_{2} \mathrm{~S}$ selama 5 menit pada suhu $60^{\circ} \mathrm{C}$ untuk menghilangkan belerang, serta pencucian $\mathrm{NaOCl}$ untuk memutihkan serat.
Di antara serat-serat selulosa regenerasi, kadar air serat rayon viskosa adalah yang paling cocok untuk kulit manusia. Serat viskosa memiliki keunggulan proses pemintalan yang baik, nyaman dipakai, tidak mudah menghasilkan listrik statis, memiliki nuansa seperti sutera, serta lebih biodegradable daripada kapas. Serat viskosa dapat dicampur dengan semua jenis serat, baik serat alami maupun sintetis. Serat viskosa menjadi alternatif paling penting untuk kapas dan serat alami lainnya di banyak negara. Karena sifatnya tersebut serat rayon viskosa memiliki aplikasi yang luas dalam industri.

Modifikasi dilakukan untuk meningkatkan sifat fisik dan mekanis serat viskosa melalui serangkaian reaksi kimia seperti esterifikasi, eterifikasi, reaksi silang, dan reaksi okulasi. Saat ini pengembangan modifikasi serat viskosa berfokus pada peningkatan sifat tahan api (Chen et al., 2006), antibakteri (Bajpai et al., 2011), penyerap kelembaban, pewarnaan, dan sifat adsorpsi. Namun komposit serat viskosa dengan kitosan, asam polilaktat dan partikel nano perak juga telah banyak dipelajari dan diterapkan (C. Zhang et al., 2018). Trend aplikasi nano teknologi dalam industri tekstil berfokus untuk menghasilkan tekstil pintar multifungsi atau tekstil yang memiliki fungsi khusus (El-Kheir et al., 2018).

Meskipun menggunakan karbon disulfida yang beracun, proses viskosa tetap dominan diantara teknologi produksi serat lainnya, karena kualitas serat yang baik dan mampu menghasilkan berbagai jenis serat berbeda mulai dari serat standar hingga serat mirip katun dan serat teknis yang sangat kuat (Sixta et al., 2015). Selain itu produksi yang berkelanjutan dan murahnya bahan baku menjadi nilai utama proses viskosa dalam industri tekstil. Namun karena keterbatasan teknologi produksi, proses pembuatannya masih menyebabkan polusi (Yu and Wan, 2017). Kelemahan lain serat viskosa adalah kekuatan sobek basah dan kering yang rendah, elongasi tinggi, mudah terbakar, dan ketahanan warna luntur yang rendah (Zhang et al., 2018; El-Kheir et al., 2018; Baker, 2018). Lebih dari 2 ton bahan kimia (seperti karbon disulfida, natrium hidroksida, asam sulfat) dan sejumlah besar air bersih diperlukan untuk tiap ton serat viskosa yang diproduksi (Hermanutz et al., 2008). 


\section{Metode Alternatif}

Walaupun termasuk metode komersial utama dunia saat ini, proses viskosa masih memiliki potensi bahaya terhadap lingkungan dan kesehatan karena penggunaan $\mathrm{CS}_{2}$. Harga $\mathrm{CS}_{2}$ yang mahal menyebabkan perlunya upaya untuk recovery $\mathrm{CS}_{2}$ sehingga akan meningkatkan biaya investasi untuk instalasi recovery system. Hal-hal tersebut telah mendorong penelitian untuk mencari teknologi yang lebih efisien dan aman untuk memperoleh serat tekstil dari selulosa.

\subsection{Proses Lyocell}

Prinsip dasar proses lyocell dikembangkan tahun 1976 oleh AEC (American Enka Corp, Amerika Serikat) dan ARLO (Akzo Research Lab. Obernburg, Jerman) dan dipatenkan pada 1980. Akzo Fibers memberikan lisensi kepada Lenzing tahun 1987 dan Courtaulds pada 1990. Lenzing memulai produksi serat di Austria pada tahun 1997 (Ullmann et al., 2011). Selanjutnya perusahaan yang berbeda menghasilkan nama merek tersendiri untuk serat dari proses ini seperti Tencel (Lenzing), Alceru (TITK Rudolstadt), Newell (Akzo Nobel), Acelon (Greencell) dan Excel (Grasim).

Proses lyocell merupakan proses yang relatif baru dibandingkan proses viskosa, yaitu serat selulosa diperoleh dari melarutkan selulosa langsung dalam pelarut lalu dipilin menjadi serat. Proses ini sangat tergantung pada kemampuan pelarut yang digunakan untuk melarutkan selulosa. Ada banyak pelarut organik polar yang tersedia seperti dimetil sulfoksida (DMSO), dimetil-formamida (DMF), dimetil asetamida (DMAC), N-nitrosodimetilamina (NDMA), heksametilfosfor-amida (HMPA), N-methyl morpholine-N-oxide (NMMO), dan lain-lain. Diantara berbagai pelarut yang digunakan, hanya ada dua pelarut yang memiliki kemampuan tinggi untuk melarutkan selulosa yaitu larutan ionik dan NMMO (Sayyed, Deshmukh and Pinjari, 2019).

NMMO memiliki bagian $\mathrm{N}-\mathrm{O}$ aktif dengan karakter dipolar kuat. Karena ini, gugus oksigen membentuk satu atau dua ikatan hidrogen dengan anhidrat glukopiranosa (AGU) di selulosa yang diketahui bahwa tiga ikatan-H selulosa dapat diserang secara bersamaan. Ini mengarah pada pembelahan ikatan hidrogen antar molekul rantai selulosa dan memfasilitasi pembentukankompleks yang kuat antara hidroksil selulosa $(-\mathrm{OH})$ dan kelompok NO dari NMMO. Kuatnya interaksi selulosa dan NMMO menghasilkan larutan selulosa yang homogen, yang mengubah sifat fisik dan volume struktur selulosa secara signifikan. Perubahan ini diperlukan agar polimer selulosa dapat dipintal (Pinkert, Marsh and Phang, 2010). Prinsip proses ini adalah selulosa dilarutkan dalam pelarut NMMO yang menghasilkan larutan selulosa homogen, kemudian larutan ini diekstrusi melalui spinneret dalam bentuk filamen diikuti dengan memisahkan pelarut dalam spin bath. Pemulihan bahan pelarut ini mencapai lebih dari 99\% sehingga membantu dalam mengurangi limbah. Pelarut NMMO sendiri tidak beracun dan limbah cair yang dihasilkan tidak berbahaya (Sayyed, Deshmukh and Pinjari, 2019). Pembuatan serat lyocell (Gambar 6) membutuhkan waktu 3 jam, lebih cepat dibandingkan proses pembuatan serat stapel viskosa yang membutuhkan waktu 40 jam. Selain itu, proses lyocell membutuhkan lebih sedikit energi dan air (Venkatesan and Periyasamy, 2017).

Proses lyocell NMMO memiliki beberapa kelemahan seperti adanya reaksi samping oksidatif, ketidakstabilan terhadap suhu, memerlukan suhu yang tinggi untuk pelarutan selulosa, serta keseragaman hasil serat yang rendah (Khalil et al., 2015; Mohd et al., 2017). Pembentukan produk samping dari reaksi $\mathrm{NMMO} /$ selulosa cukup besar sehingga menyebabkan efek merusak seperti degradasi selulosa, perubahan warna serat sementara hingga permanen, penurunan kinerja produk serat, dekomposisi NMMO, serta peningkatan konsumsi bahan penstabil suhu (Rosenau et al., 2001). Pengembangan proses NMMO ini termasuk sangat lambat disebabkan kompleksnya proses

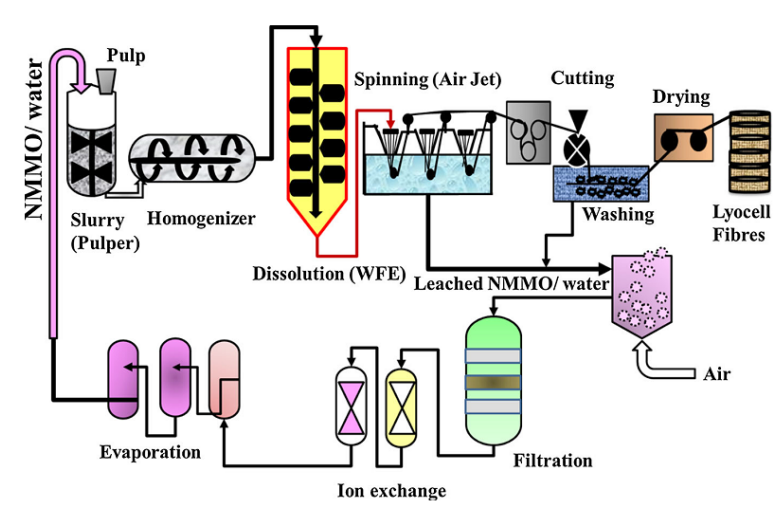

Gambar 6. Alur Proses Pembuatan Serat Lyocell (Sayyed, Deshmukh and Pinjari, 2019). 
pelarutan dan pemulihan bahan pelarut yang digunakan (Cai et al., 2009). Meskipun memiliki banyak keuntungan, proses lyocell belum dapat menggantikan proses viskosa karena pelarut NMMO yang tidak stabil secara suhu sehingga membutuhkan investasi besar untuk teknologi keselamatan (Hermanutz et al., 2008). Dengan demikian hambatan utama proses ini adalah biaya produksi lyocell yang lebih tinggi daripada kapas atau rayon viskosa (Kumar and Christopher, 2017; Zhang et al., 2008; Ali et al., 2018).

\subsection{Proses Larutan Ionik}

Larutan ionik memiliki keunggulan mampu melarutkan selulosa dengankadartinggi(15-20\%), kemudahan dalam daur ulang bahan kimia, sifat pelarutan yang baik, dan memiliki stabilitas pada suhu tinggi (Mohd et al., 2017). Stabilitas suhu yang sangat baik dan tidak mudah menguap atau terbakar ini memberikan keuntungan ketika proses larutan ionik digunakan dalam proses produksi. Selain itu pelarut dalam larutan ionik hampir seluruhnya dipulihkan setelah digunakan $(>99,5 \%)$ dan dapat digunakan kembali. Jumlah bahan pembantu yang diperlukan dan volume air limbah yang dihasilkan jauh lebih rendah daripada proses viskosa dan mirip dengan proses lyocell NMMO. (Hermanutz et al., 2008).

Pada dasarnya proses larutan ionik dan NMMO adalah serupa karena pada proses larutan ionik ini serat selulosa diperoleh mengikuti teknik lyocell berbasis NMMO dengan menggunakan proses pemintalan jet kering basah (Gambar 7). Filamen cair pertama kali dilewatkan melalui celah udara sebelum direndam dalam tangki koagulasi hingga terbentuk serat selulosa regenerasi (Sayyed, Deshmukh and Pinjari, 2019).

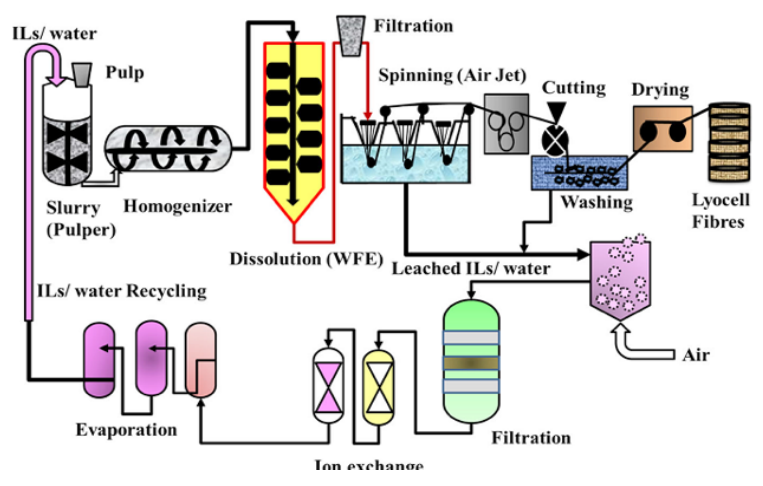

Gambar 7. Alur Proses Pembuatan Serat Larutan Ionik (Sayyed, Deshmukh and Pinjari, 2019).
Larutan-larutan ionik biasanya dibuat dari imidazolium, pyridinium, kation dan anion ammonium organik, atau struktur kompleks seperti hexafluorophosphate dan yang lainnya. Untuk melarutkan selulosa diketahui bahwa larutan ionik golongan imidazolium seperti halide, phosphonate, carboxylate, dan thiocyanate memberikan hasil pelarutan terbaik (Mohd et al., 2017). Contoh golongan imidazolium seperti butilmethilimida-zolium klorida (BMIMCl), 1-Etil-3-methilimida-zolium klorida (EMIMCl), 1-Butil-3-metilimida-zolium asetat (BMIMAc), dan 1-Etil-3-metilimida-zolium asetat (EMIMAc) memberikan pelarutan selulosa yang baik (Kosan, Michels and Meister, 2008). Pelarutan selulosa terjadi ketika anion dan kation larutan ionik membentuk ikatan hidrogen dengan atom hidrogen dan atom oksigen selulosa, yang menempatkan tepat diantara gugus hidroksil C6 dan C3 rantai selulosa. Larutan ionik mampu mengarahkan pembelahan rantai selulosa dengan efek sinergis dari anion dan kation (Mohd et al., 2017).

Proses larutan ionik selain memiliki potensi dan keunggulan, juga masih memiliki sejumlah kekurangan. Larutan ionik berbasis imidazolium yang mengandung anion klorida mungkin akan terbatas aplikasi praktisnya dalam derivatisasi selulosa karena membutuhkan suhu tinggi untuk melarutkan selulosa, sehingga dapat terjadi dekomposisi larutan ionik dan menghasilkan beberapa senyawa organohalogenida (Sayyed, Deshmukh and Pinjari, 2019). Selain itu larutan ionikklorida memiliki viskositasyang relatiftinggi dan sifat korosif yang tidak diinginkan (Pinkert, Marsh and Phang, 2010). Viskositas larutan ionik dengan selulosa dapat menunjukkan perilaku temperatur non-Arrhenius sehingga meningkat secara tak terduga dengan cepat khususnya ketika mendekati 0 hingga $40{ }^{\circ} \mathrm{C}$. Hal ini mempengaruhi difusi ion dan transfer massa dan menjadi masalah penting untuk industrialisasi (Wang, $\mathrm{Lu}$ and Zhang, 2016). Potensi ketidakstabilan suhu dan reaksi samping juga dilaporkan telah terjadi ketika menggunakan larutan ionik dari daur ulang, sehingga termostabilitas selulosa dalam larutan ionik menurun secara signifikan (Wang, Lu and Zhang, 2016).

Beberapa larutan ionik lainnya diketahui tidak mampu untuk melarutkan selulosa, sehingga pencarian larutan ionik dengan kemampuan melarutkan selulosa masih didasarkan pada coba-coba (Pinkert, Marsh and Phang, 2010). Diperlukan peningkatan larutan ionik yang 
sudah ada agar menjadi bebas dari senyawa halogen, tidak beracun, dan berviskositas rendah. Penelitian dan optimasi lebih lanjut juga diperlukan untuk membuat proses larutan ionik ini dapat berkelanjutan saat aplikasi di industri (Sayyed, Deshmukh and Pinjari, 2019).

Permasalahan lainnya seperti kesulitan saat proses pelarutan selulosa, pemintalan serat dari larutan selulosa berviskositas tinggi, dan recovery bahan kimia pelarut perlu diatasi untuk produksi skala besar. Hal-hal tersebut berpengaruh langsung pada biaya produksi serat larutan ionik dan menyebabkan proses regenerasi serat dari larutan ionik lebih mahal dibandingkan dengan proses-proses lainnya. Karena keterbatasan inilah proses larutan ionik masih belum dikomersialkan (Sayyed, Deshmukh and Pinjari, 2019).

\subsection{Proses Modal}

Serat modal didefinisikan dalam Standar Internasional ISO 206: 999 (E) sebagai serat high-wet modulus yang dihasilkan dari regenerasi selulosa menggunakan proses viskosa tertentu dan komposisi larutan perendam tertentu sehingga memungkinkan orientasi molekul yang lebih besar selama peregangan dan pembentukan serat. Serat modal diperoleh dari modifikasi proses viskosa sehingga serat rayonnya bersifat high-wet modulus. Filamen serat modal mampu lebih diregangkan dibandingkan serat viskosa biasa (Wang, Lu and Zhang, 2016). Serat modal dikembangkan dan menjadi merek dagang dari Lenzing AG, dimana serat modal ini dibuat dari kayu beech (Mamun et al., 2017; Venkatesan and Periyasamy, 2017). Serat modal memiliki kristalinitas lebih rendah dari serat lyocell, menyerap kelembaban lebih tinggi dari serat lyocell dan viskosa, sementara stabilitas suhu serat modal lebih rendah dari serat lyocell dan viskosa (Ramamoorthy, Skrifvars and Persson, 2015).

Teknologi produksi dan proses serat modal pada dasarnya sama dengan viskosa, menggunakan alkali untuk membuat larutan selulosa dan membentuk serat melalui pendinginan. Namun, kemajuan tertentu telah dibuat dalam teknologi serat modal sehingga membuat proses ini memenuhi persyaratan serat ramah lingkungan dan hijau (Yu and Wan, 2017). Beberapa perbedaan serat modal dengan serat rayon viskosa biasa yaitu proses modal menggunakan hanya bahan baku kayu beech, sedangkan proses viskosa biasa dapat menggunakan banyak jenis kayu (Ullmann et al., 2011). Penggunaan serat beech menghasilkan serat modal yang halus dan setara dengan sutera alami. Hasil pengukuran faktor kelembutan menunjukkan bahwa serat modal dua kali lebih lembut dari kapas. Serat modal juga 50\% lebih higroskopis per satuan volume daripada kapas (Moses and Gnanapriya, 2016). Pada proses modal, pemeraman (ageing) alkalisasi selulosa dan pematangan (ripening) dalam xantasi tidak lagi diperlukan sehingga konsentrasi bahan kimia berkurang, kecepatan koagulasi selulosa menjadi berkurang, karena itu memberikan lebih banyak waktu untuk proses peregangan serat. Prinsip produksi serat viskosa high-tenacity adalah kecepatan regenerasi selulosa perlu dikurangi (Chen, 2015). Kelemahan proses modal adalah serat yang dihasilkan lebih mahal daripada serat rayon viskosa biasa ataupun kapas.

\subsection{Proses Karbamat}

Proses selulosa karbamat pertama kali dikembangkan oleh Neste Oy, mendapat banyak perhatian karena selulosa karbamat dapat diproses seperti selulosa xantat pada proses viskosa, tetapi tanpa pelepasan senyawa sulfur yang beracun (Sixta et al., 2015; Hummel et al., 2019). Proses karbamat (Gambar 8) ini menggunakan urea sebagai pengganti $\mathrm{CS}_{2}$ untuk bereaksi dengan selulosa, hingga diperoleh selulosa karbamat yang larut dan dapat dibentuk dalam larutan natrium hidroksida. Selanjutnya selulosa karbamat diregenerasi menjadi serat pada sistem pemintalan basah mengikuti proses viskosa yang telah ada, namun tanpa penggunaan seng atau logam berat lainnya di bak koagulasi (Qi, 2017).

Keuntungan proses ini adalah selulosa karbamat yang terbentuk memiliki stabilitas yang relatif tinggi pada suhu kamar sehingga memungkinkan penyimpanan selama lebih dari setahun. Dengan demikian sintesis selulosa karbamat dapat dilakukan pada suatu lokasi dan kemudian dikirim ke lokasi lain untuk pemrosesan selanjutnya (seperti pabrik pemintalan) (Qi, 2017).

Meskipun memiliki beberapa kelebihan dibandingkan proses lainnya, tetapi sifat-sifat serat selulosa karbamat yang dihasilkan tidak lebih baik daripada serat rayon viskosa reguler dan tidak dapat mencapai angka tenacity serat modal atau serat viskosa termodifikasi lainnya. Hal ini mungkin menjadi alasan utama mengapa 


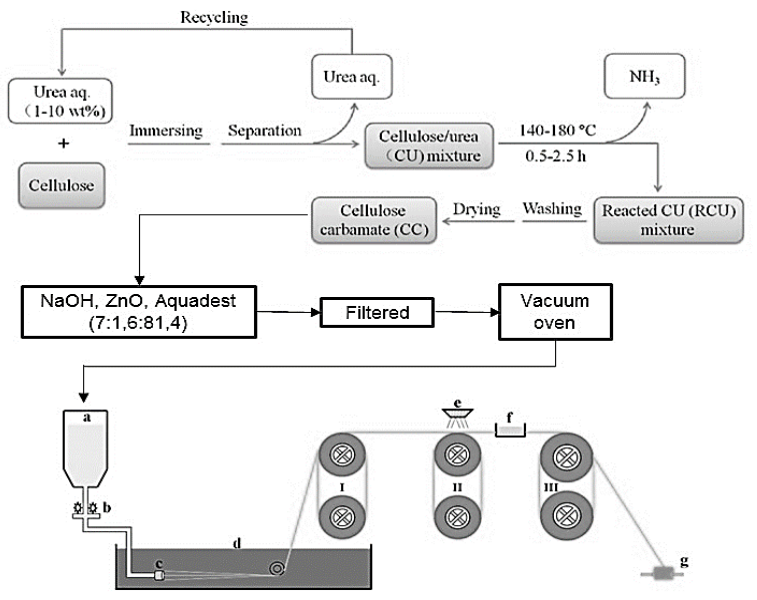

Gambar 8. Alur Proses Pembuatan Serat Karbamat (Fu et al., 2014; Fu et al., 2015)

proses selulosa karbamat, meskipun ada beberapa perbaikan belum mendapatkan komersialisasi sejauh ini. (Sixta et al., 2015).

Meskipun memiliki sejumlah keunggulan dibandingkan proses viskosa biasa, proses karbamat belum diterapkan oleh industri sampai sekarang. Hal ini disebabkan adanya persyaratan proses tertentu yang harus dipenuhi seperti kebutuhan bahan katalis, pelarut organik, waktu reaksi yang lama, dan suhu yang tinggi (Qi, 2017). Selulosa karbamat dapat disintesis dengan menggunakan reaktor $\mathrm{CO}_{2}$ supercritical ataupun radiasi gelombang mikro. Namun penerapan untuk skala industri masih menjadi tantangan tersendiri.

Hasil Life Cycle Assessment (LCA) menunjukkan bahwa empat produk serat regenerasi selulosa komersial yaitu Tencel,
Modal, Viscose (Austria) dan Tencel (2012), memiliki keseluruhan dampak lingkungan yang rendah dibandingkan serat sintetis PET (Polietilena tereftalat) dan PP (polipropilena). Kapas diidentifikasi sebagai pilihan yang paling tidak disukai karena dampak ekotoksisitasnya yang tinggi, eutrofikasi, serta penggunaan air dan penggunaan lahan (Shen, Worrell and Patel, 2010). Sifat-sifat serat berdasarkan proses pembuatannya dari beberapa literatur disajikan dalam Tabel 3.

\section{Kesimpulan}

Proses viskosa sebagai metode komersial tertua dan paling penting dalam derivatisasi selulosa masih menggunakan bahan kimia yang berbahaya untuk lingkungan dan kesehatan manusia. Proses karbamat menggunakan metode derivatisasi yang lebih ramah lingkungan dan dapat menggunakan teknologi pemintalan viskosa yang sudah berjalan, namun karakteristik serat hasil regenerasi selulosa tidak sebaik proses modal maupun proses viskosa biasa. Dibandingkan dengan metode derivatisasi kimia, menggunakan pelarut langsung jauh lebih sederhana seperti pada proses lyocell dan larutan ionik, mudah membentuk selulosa, serta ramah lingkungan, sehingga memiliki potensi untuk diterapkan. Namun mekanisme detil proses pelarutan langsung dan regenerasi selulosa ini masih diteliti, dan penggunaan pelarut-pelarut ini juga memiliki tantangannya sendiri yang harus diatasi sebelum siap menggantikan proses viskosa seutuhnya.

Tabel 3. Referensi Sifat Serat berdasakan Proses Pembuatan

\begin{tabular}{|c|c|c|c|c|c|c|c|c|}
\hline Sifat & Satuan & Cupro & Asetat & Viskosa & Lyocell & Lar. Ionik & Modal & Karbamat \\
\hline Dry tenacity & $\mathrm{g} / \mathrm{den}$ & $1,7-2,3$ & $1,2-1,4$ & $2,4-2,9$ & $4,5-5,0$ & $3,5-4,1$ & $3,9-4,5$ & $1,4-2,9$ \\
\hline Wet tenacity & $\mathrm{g} / \mathrm{den}$ & $1,0-1,4$ & $0,9-1,0$ & $1,1-1,6$ & $3,9-4,0$ & $2,3-3,1$ & $2,8-3,3$ & $0,4-1,0$ \\
\hline $\begin{array}{l}\text { Dry } \\
\text { elongation }\end{array}$ & $\%$ & $7-24$ & $25-35$ & $17-25$ & $11-16$ & $7-8$ & $14-16$ & $8-27$ \\
\hline Wet elongation & $\%$ & $16-43$ & $35-45$ & $21-30$ & $16-18$ & $9-12$ & $16-18$ & $10-27$ \\
\hline Literatur & & $\begin{array}{l}\text { (Woodings, } \\
2001 \text { ) }\end{array}$ & $\begin{array}{l}\text { (Chen, } \\
2015)\end{array}$ & $\begin{array}{l}\text { (S. } \\
\text { Zhang } \\
\text { et al., } \\
2018 \text { ) }\end{array}$ & $\begin{array}{l}\text { (S. Zhang } \\
\text { et al., } \\
2018 \text { ) }\end{array}$ & $\begin{array}{l}\text { (Kosan, } \\
\text { Michels } \\
\text { and } \\
\text { Meister, } \\
\text { 2008; } \\
\text { Jiang et al., } \\
\text { 2012) }\end{array}$ & $\begin{array}{l}\text { (Ali } \\
\text { et al., } \\
2018)\end{array}$ & $\begin{array}{l}\text { (Lehmann, } \\
\text { 2015) }\end{array}$ \\
\hline
\end{tabular}




\section{Ucapan Terima Kasih}

Terima kasih disampaikan kepada rekan-rekan kerja atas usaha dan kerjasama yang baik.

\section{Daftar Pustaka}

Ali, E. M. T., Iqbal, M. A., Hossain, S. . M., Alam, M. K. and Molla, J. B. (2018) 'Study on Blending Effect of Cotton with Viscose for Increasing Yarn Properties', DIU Journal of Science and Technology, 13(1).

Andemars, S. G., Silk, C., Bernigaud, L. H., Despeissis, L., Cross, C. F., Bevan, E. J., Beadle, C., Rayon, V., Courtauld, S. and Corporation, A. V. (2018) 'Rayon', pp. 195197. doi: 10.1007/978-3-319-78766-4.

Bajpai, V., Bajpai, S., Jha, M. K., Dey, A. and Ghosh, S. (2011) 'Microbial Adherence on Textile Materials: A Review', Journal of Environmental Research \& Development, 5(3), pp. 666-672.

Baker, I. (2018) Fifty Materials That Make the World, Springer Nature. Springer International Publishing. doi: 10.1007/978-3-319-78766-4.

Basit, A., Latif, W., Ashraf, M., Rehman, A., Iqbal, K., Maqsood, H. S., Jabbar, A. and Baig, S. A. (2019) 'Comparison of Mechanical and Thermal Comfort Properties of Tencel Blended with Regenerated Fibers and Cotton Woven Fabrics', AUTEX Research Journal, 19(1), pp. 80-85. doi: 10.1515/aut-20180035.

Cai, T., Zhang, H., Guo, Q., Shao, H. and Hu, X. (2009) 'Structure and Properties of Cellulose Fibers from Ionic Liquids', Journal of Applied Polymer Science, 115, pp. 1047-1053. doi: 10.1002/app.31081.

Chen, J. (2015) Synthetic Textile Fibers: Regenerated Cellulose Fibers, Textiles and Fashion. Elsevier Ltd. doi: 10.1016/B978-184569-931-4.00004-0.

Chen, S., Zheng, Q., Ye, G. and Zheng, G. (2006) 'Fire-RetardantPropertiesoftheViscoseRayon Containing Alkoxycyclotriphosphazene', Journal of Applied Polymer Science, 102, pp. 698-702. doi: 10.1002/app.24217.

Cuissinat, C., Navard, P. and Heinze, T. (2008) 'Swelling and Dissolution of Cellulose, Part V: Cellulose Derivatives Fibres in Aqueous Systems and Ionic Liquids', Cellulose, 15, pp. 75-80. doi: 10.1007/s10570-007-9159-3.

El-Kheir, A. A. A., Ezzat, M., Bassiouny, F. and ElGabry, L. K. (2018) 'Development of Some Functional Properties on Viscose Fabrics Using Nano Kaolin', Cellulose. Springer Netherlands, 25(8), pp. 4805-4818. doi: 10.1007/s10570-018-1865-5.
Freitas, A., Zhang, G. and Mathews, R. (2017) 'Water Footprint Assessment of Polyester and Viscose and Comparison to Cotton', Water Footprint Network, p. 89. Available at: https:// waterfootprint.org/media/downloads/WFA Polyester_and_Viscose_2017.pdf.

Fu, F., Xu, M., Wang, H., Wang, Y., Ge, H. and Zhou, J. (2015) 'Improved Synthesis of Cellulose Carbamates with Minimum Urea Based on an Easy Scale-up Method', ACS Sustainable Chemistry \& Engineering. doi: 10.1021/acssuschemeng.5b00219.

Fu, F., Yang, Q., Zhou, J., Hu, H., Jia, B. and Zhang, L. (2014) 'Structure and Properties of Regenerated Cellulose Filaments Prepared from Cellulose Carbamate $-\mathrm{NaOH} / \mathrm{ZnO}$ Aqueous Solution', ACS Sustainable Chemistry \& Engineering, 2, pp. 2604-2612. doi: $10.1021 / \mathrm{sc} 500559 \mathrm{~g}$.

Hämmerle, F. M. (2011) 'The Cellulose Gap (The Future of Cellulose Fibres)', Lenzinger Berichte, 89, pp. 12-21.

Hermanutz, F., Gahr, F., Uerdingen, E., Meister, F. and Kosan, B. (2008) 'New Developments in Dissolving and Processing of Cellulose in Ionic Liquids', Macromol. Symp., 262, pp. 23-27. doi: 10.1002/masy.200850203.

Hummel, M., Michud, A., Ma, Y., Roselli, A., Stepan, A., Hellstén, S., Asaadi, S. and Sixta, H. (2019) 'High Performance Lignocellulosic Fibers Spun from Ionic Liquid Solution', in Cellulose Science and Technology: Chemistry, Analysis, and Applications, First Edition, pp. 341-370. doi: 10.1002/9781119217619.ch14.

Jiang, G., Huang, W., Li, L., Wang, X., Pang, F., Zhang, Y. and Wang, H. (2012) 'Structure and Properties of Regenerated Cellulose Fibers from Different Technology Processes', Carbohydrate Polymers. Elsevier Ltd., 87(3), pp. 2012-2018. doi: 10.1016/j. carbpol.2011.10.022.

Kauffman, G. B. (1993) 'Rayon: The First SemiSynthetic Fiber Product', Journal of Chemical Education, 70(11), pp. 887-893. doi: 10.1021/ ed070p887.

Keshipour, S. and Maleki, A. (2019) 'Modification of Cellulose', in Polymers and Polymeric Composites: A Reference Series. Springer Nature Switzerland, pp. 436-473. doi: 10.1007/978-3-319-77830-3 17.

Khalil, H. P. S. A., Davoudpour, Y., Bhat, A. H., Rosamah, E. and Tahir, P. M. (2015) 'Electrospun Cellulose Composite Nanofibers', in Handbook of Polymer Nanocomposites. Processing, Performance and Application. Springer-Verlag Berlin Heidelberg, pp. 191-227. doi: 10.1007/9783-642-45232-1_61. 
Kopcke, V. (2010) Conversion of Wood and Nonwood Paper-grade Pulps to Dissolving-grade Pulps, Doctoral Thesis. Royal Institute of Technology Sweden.

Kosan, B., Michels, C. and Meister, F. (2008) 'Dissolution and Forming of Cellulose with Ionic Liquids', Cellulose, 15, pp. 59-66. doi: 10.1007/s10570-007-9160-X.

Kumar, H. and Christopher, L. P. (2017) 'Recent Trends and Developments in Dissolving Pulp Production and Application', Cellulose. Springer Netherlands. doi: 10.1007/s10570017-1285-y.

Latif, W., Basit, A., Rehman, A., Ashraf, M., Iqbal, K., Baig, S. A. and Maqsood, S. (2018) 'Study of Mechanical and Comfort Properties of Modal with Cotton and Regenerated Fibers Blended Woven Fabrics', Journal of Natural Fibers. Taylor \& Francis, pp. 1-10. doi: 10.1080/15440478.2018.1441084.

Law, R. C. (2004) 'Application of Cellulose Acetate', Macromol. Symp., 208, pp. 255265. doi: 10.1002/masy.200450410.

Lehmann, A. (2015) 'Dissolution and Processing of Cellulose from Alkaline Media - Carbamate and Viscose System', COST FP1205 Training School, pp. 1-66.

Li, D., Sevastyanova, O. and Ek, M. (2012) 'Pretreatment of Softwood Dissolving Pulp with Ionic Liquids', Holzforschung, 66, pp. 935-943. doi: 10.1515/hf-2011-0180.

Mamun, M. H., Mostofa, A., Hossain, M. A., Khan, M., Zakaria, M. and Yeasmin, M. S. (2017) 'Effect of Reactive Groups of Reactive Dyes on Dyeing of Modal Fabrics', International Journal of Textile Science, 6(6), pp. 158-164. doi: 10.5923/j.textile.20170606.04.

Manian, A. P., Pham, T. and Bechtold, T. (2018) 'Regenerated Cellulosic Fiber', in Handbook of Properties of Textile and Technical Fibres. Elsevier, pp. 329-343. doi: 10.1016/B978-008-101272-7.00010-9.

Mohd, N., Draman, S. F. S., Salleh, M. S. N. and Yusof, N. B. (2017) 'Dissolution of Cellulose in Ionic Liquid: A Review', Proceedings of the 6th International Advances in Applied Physics and Materials Science Congress \& Exhibition,pp. 1-14. doi: 10.1063/1.4975450.

Moses, J. J. and Gnanapriya (2016) 'A Study on Modal Fabric using Formic Acid Treatment for K/S, SEM and Fourier Transform Infrared Spectroscopy', Oriental Journal of Chemistry, 32(2), pp. 1099-1110. doi: $10.13005 / \mathrm{ojc} / 320235$.

Noerati, Gunawan, Ichwan, M. and Sumihartati, A. (2013) Teknologi Tekstil, Bahan Ajar Pendidikan dan Pelatihan Guru. Sekolah Tinggi Teknologi Tekstil.
Ozturk, H. B. and Bechtold, T. (2008) 'Splitting Tendency of Cellulosic Fibers . Part 3: Splitting Tendency of Viscose and Modal Fibers', Cellulose, 15, pp. 101-109. doi: 10.1007/s10570-007-9149-5.

Pinkert, A., Marsh, K. N. and Phang, S. (2010) 'Reflections on the Solubility of Cellulose', Ind. Eng. Chem. Res., 49, pp. 11121-11130. doi: 10.1021/ie1006596.

Purwita, C. A. and Sugesty, S. (2018) 'Pembuatan dan Karakterisasi Dissolving Pulp Serat Panjang dari Bambu Duri (Bambusa blumeana)', Jurnal Selulosa, 8(1), pp. 2132. doi: 10.25269/jsel.v8i01.232.

Qi, H. (2017) Novel Functional Materials Based on Cellulose, SpringerBriefs in Applied Sciences and Technology. doi: 10.1007/9783-319-49592-7.

Ramamoorthy, S. K., Skrifvars, M. and Persson, A. (2015) 'A Review of Natural Fibers Used in Biocomposites: Plant, Animal and Regenerated Cellulose Fibers', Polymer Reviews, 55, pp. 107-162. doi: 10.1080/15583724.2014.971124.

Rosenau, T., Potthast, A., Sixta, H. and Kosma, P. (2001) 'The Chemistry of Side Reactions and Byproduct Formation in the System NMMO/ Cellulose (Lyocell Process)', Progress in Polymer Science, 26, pp. 1763-1837. doi: 10.1016/S0079-6700(01)00023-5.

Rustemeyer, P. (2004) 'History of CA and Evolution of the Markets', Macromol. Symp., 208, pp. 1-6. doi: 10.1002/masy.200450401.

Sango, C., Kaur, P., Bhardwaj, N. K. and Sharma, J. (2018) 'Bacterial Cellulase Treatment for Enhancing Reactivity of Pre- Hydrolysed Kraft Dissolving Pulp for Viscose', 3 Biotech. Springer Berlin Heidelberg, 8(271). doi: 10.1007/s13205-018-1293-0.

Sayyed, A. J., Deshmukh, N. A. and Pinjari, D. V (2019) 'A Critical Review of Manufacturing Processes Used in Regenerated Cellulosic Fibres: Viscose, Cellulose Acetate, Cuprammonium, $\mathrm{LiCl} /$ DMAc, Ionic Liquids, and NMMO Based Lyocell', Cellulose. Springer Netherlands, 123456789 , p. 28 . doi: 10.1007/s10570019-02318-y.

Shen, L., Worrell, E. and Patel, M. K. (2010) 'Environmental Impact Assessment of Man-Made Cellulose Fibres', Resources, Conservation \& Recycling. Elsevier B.V., 55(2), pp. 260-274. doi: 10.1016/j. resconrec.2010.10.001.

Singh, Z. and Bhalla, S. (2017) 'Toxicity of Synthetic Fibres \& Health', Advance Research in Textile Engineering, 2(1), pp. 1-5. doi: 10.26420/advrestexteng.2017.1012. 
Sixta, H. (2006) Handbook of Pulp, Wiley - VCH. doi: 10.1002/9783527619887.

Sixta, H. (2016) 'Postgraduate Course on Cellulose Chemistry Dissolving Pulps'. Aalto University School of Chemical Technology, p. 64.

Sixta, H., Iakovlev, M., Testova, L., Roselli, A., Hummel, M., Borrega, M., Heiningen, A. van, Froschauer, C. and Schottenberger, $\mathrm{H}$. (2013) 'Novel Concepts of Dissolving Pulp Production', Cellulose, 20, pp. 1547-1561. doi: 10.1007/s10570-013-9943-1.

Sixta, H., Michud, A., Hauru, L., Asaadi, S., Ma, Y., King, A. W. T., Kilpeläinen, I., Hummel, M., Ma, Y., Cross, C., Bevan, E. J. and Beadle, C. (2015) 'Ioncell-F : A HighStrength Regenerated Cellulose Fibre', Nordic Pulp and Paper Research Journal, 30(1), pp. 43-57. doi: 10.3183/npprj-201530-01-p043-057.

Strunk, P. (2012) Characterization of Cellulose Pulps and The Influence of Their Properties on The Process and Production of Viscose and Cellulose Ethers. Umea University.

Suwantong, O. and Supaphol, P. (2015) 'Applications of Cellulose Acetate Nanofiber Mats', in Handbook of Polymer Nanocomposites. Processing, Performance and Application. Springer-Verlag Berlin Heidelberg, pp. 355-368. doi: 10.1007/9783-642-45232-1 70.

Truscott, L., Tan, E. and Opperskalski, S. (2018) 'Preferred Fiber \& Materials Market Report 2018', Textile Exchange, pp. 1-96. Available at: https://textileexchange.org.

Ullmann, F., Gerhartz, W., Yamamoto, Y. S., Campbell, F. T., Pfefferkorn, R., Rounsaville, J. F. and Ullmann, F. (2011) Ullmann's Encyclopedia of Industrial Chemistry, Wiley - VCH. doi: 10.1002/14356007.
Venkatesan, H. and Periyasamy, A. P. (2017) 'EcoFibers in the Textile Industry', in Handbook of Ecomaterials. Springer International Publishing AG. doi: 10.1007/978-3-31948281-1 25-1.

Wang, S., Lu, A. and Zhang, L. (2016) 'Recent Advances in Regenerated Cellulose Materials', Progress in Polymer Science. Elsevier Ltd, 53, pp. 169-206. doi: 10.1016/j. progpolymsci.2015.07.003.

Woodings, C. (2001) Regenerated Cellulose Fibres, Woodhead Publishing Ltd and CRC Press LLC. Woodhead Publishing Ltd and CRC Press LLC. doi: 10.1533/9781855737587.

$\mathrm{Yu}$, M. and Wan, J. (2017) 'Environmental Friendly Development of Regenerated Cellulose Fiber Production', Asia-Pacific Engineering and Technology Conference (APETC), pp. 760-765.

Zhang, C., Ren, J., Ma, Y., Liu, Y., Tang, Y. and Qin, S. (2018) 'Preparation and Adsorption Properties of Amphoteric Viscose Fiber', Iranian Polymer Journal. Springer Berlin Heidelberg, 27(9), pp. 635-644. doi: 10.1007/s13726-018-0640-7.

Zhang, H., Zhang, H., Tong, M., Shao, H. and $\mathrm{Hu}, \mathrm{X}$. (2008) 'Comparison of the Structures and Properties of Lyocell Fibers from High Hemicellulose Pulp and High AlphaCellulose Pulp', Journal of Applied Polymer Science, 107, pp. 636-641. doi: 10.1002/ app. 27129.

Zhang, S., Chen, C., Duan, C., Hu, H., Li, H., Li, J., Liu, Y., Ma, X., Stavik, J. and Ni, Y. (2018) 'Regenerated Cellulose by the Lyocell Process, a Brief Review of the Process and Properties', BioResources, 13(2), pp. 45774592. 